(S)AGE journals

Journal of Health Management

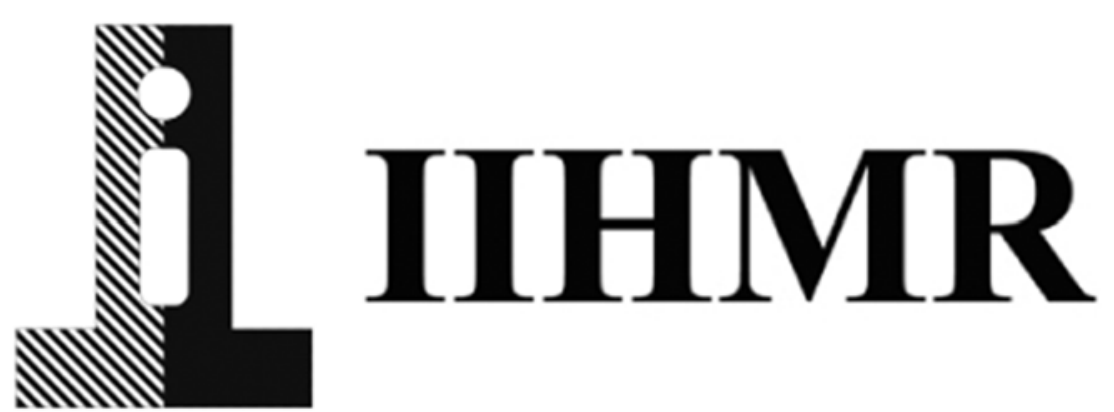

Journal Indexing \& Metrics

$\underline{\text { View } n}$

- Journal Home

- Browse Journal

- Journal Info

- Stay Connected

- Submit Paper

Article Menu

\title{
Health Communication and Hepatitis Health Management: A Study on the Awareness and Behavioural Practices in Nigeria
}

Charity Ben-Enukora, Lanre Amodu, Nelson Okorie

First Published May 22, 2019 Research Article

https://doi.org/10.1177/0972063419835128

Article information 


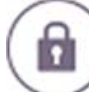

\section{Abstract}

Hepatitis has become a leading cause of death across the globe. Social lifestyle practices and behaviours that predispose individuals to contracting the disease have been identified as factors that constitute huge challenge towards the disease prevention. Against this backdrop, this study examined the residents' source of information on hepatitis disease, knowledge of the high-risk behaviours that could expose people to hepatitis infection and the effects of hepatitis awareness on current behavioural practices of the study population. The study adopted the survey design and multi-stage sampling procedure was employed. The findings revealed that the broadcast media was identified as the major source of information on hepatitis disease/prevention. Respondents' knowledge of high-risk behaviours that stimulate hepatitis infection was very low. Knowledge of hepatitis preventive measures was critically low. More so, awareness of hepatitis disease did not influence the majority of the residents to adopt preventive practices aimed at reducing the incidence of hepatitis infection. In view of these findings, the study recommends among others that information on hepatitis prevention should be more 'behaviour-centred' and interpersonal communication channels such as opinion leaders, religious leaders, community development officers and community-based health workers could be identified and recruited for hepatitis intervention.

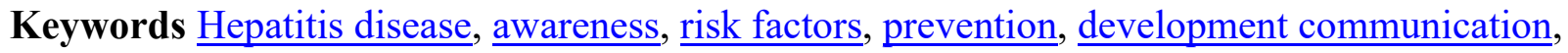
behaviour change communication

$\underline{\text { Access Options }}$

\section{Purchase Content}

Research off-campus without worrying about access issues. Find out about Lean Library here

\section{References}

Andronie, I. (2015). Economic and social factors fighting against Hepatitis B and C contagion. Retrieved from http://revecon.ro/articles/2015-1/2015-1-12.pdf

Google Scholar

Atiba, B. P., Ajao, K. O., Babalola, R. N., Awosusi, A. E, Ayeni, O. O., Ijadunola, K. T. (2014). Hepatitis B Virus infection and its modes of prevention among clinical students of Obafemi Awolowo University (OAU), Ile-Ife, Nigeria. African Journal of Medicine and Medical Sciences, 43(3), 1-7. Retrieved from https://www.ncbi.nlm.nih.gov/pubmed/26949778 Google Scholar 
Babalola, E. T., Ainabe, O. B., Okonko, I. O. (2013). Confirmation of Hepatitis B surface antigen (HBsAg) among selected tertiary institution students in Ogun State, Nigeria. Nature and Science, 11(3), 107-113. Retrieved from http://www.sciencepub.net/nature Google Scholar

Bello, S. M. (2015). Newspaper coverage of health issues in Nigeria: The frequency of reporting malaria, HIV/AIDS and polio and the effect of seeking health information on the health behaviours of newspaper readers (A thesis submitted to the Department of Media and Communication, University of Canterbury). Retrieved from https://ir.canterbury.ac.nz/handle/10092/11639

Google Scholar

Bowie, J. V., Curbow, B. A., Garza, M. A., Dreyling, E. K., Benz Scott, L. A., McDonnell, K. A. (2005). A Review of breast, cervical, and colorectal cancer screening interventions in older women. Cancer Control, 12(Suppl. 2), 58-69.

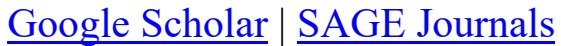

Emmanuel, D. (2011, September). Missing in the news: Roundtable examines low media coverage of Hepatitis in Nigeria. Retrieved from https://hepatitisinnigeria.WordPress.com Google Scholar

Gboeze, A. J., Ezeonu, P. O., Onoh, R. C., Ukaegbe, C. I., Nwali, M. I. (2015). Knowledge and awareness of Hepatitis B virus infection among pregnant women in Abakaliki Nigeria. Journal of Hepatitis Research, 2(3), 1-4.

Google Scholar

Hirnschall, R. (2015). There's a reason viral hepatitis has been dubbed the 'silent killer'.

Retrieved from www.who.int/mediacentre/commentaries/viral-hepatitis

Google Scholar

Kolawole, A., Kehinde, A., Tope, A., Christianah, A., Wasiu, T. (2015). The use of appropriate communication channels to understand life-threatening diseases: A study of viral hepatitis infection among Onikolobo residents in Abeokuta, Nigeria. Advances in Infectious Diseases, 5(4), 189-195.

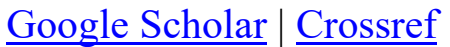

Kooffreh-Ada, M., Okpara, O., Oku, O., Okonkwo, U., Ihekwaba, A. (2015). Risk factors for chronic liver disease amongst patients receiving care in a gastroenterology practice in Calabar. Journal of Dental Medical Science, 14(12), 6-13.

Google Scholar

Leuridan, E., Van Damme, P. (2011). Hepatitis B and the need for a booster does. Oxford Journal of Medicine and Health Clinical Infectious Diseases, 53(1), 68-75.

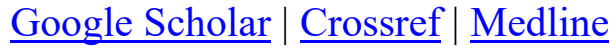


Lucy, M. R., Mathurin, P., Morgan, T. R. (2009). Alcoholic hepatitis: Review article. New England Journal of Medicine, 360(26), 2758-2769.

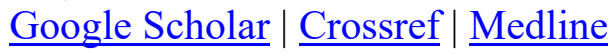

Majolagbe, O. N., Oladipo, E. K., Daniel, L. E. (2014). Prevalence and awareness of Hepatitis B infection among blood donors in Abubakar Tafawa Balewa University Teaching Hospital (ATBUTH), Bauchi, Nigeria. International Journal of Multidisciplinary and Current Research, 2, 955-960.

Google Scholar

MedlinePlus . (2009). The dangers of hepatitis: What you should know from A to E. 4, pp. $22-$ 23. Retrieved https://medlineplus.gov/.../spring09/article

Google Scholar

Muanya, C. (2015, July 31). Hepatitis on the prowl in Nigeria. The Guardian. Retrieved from https://guardian.ng/features/weekend/hepatitis-on-the-prowl-in-nigeria/

Google Scholar

Musa, B. M., Bussell, S., Borodo, M. M., Samaila, A. A., Femi, O. L. (2015). Prevalence of Hepatitis B virus infection in Nigeria, 2000-2013: A systematic review and meta-analysis. Nigerian Journal of Clinical Practice, 18, 163-172. Retrieved from http://dx.doi.org/10.4103/1119-3077.151035

Google Scholar

Ndako, J. A., Nwankiti, O. O., Echeonwu, G., Junaid, S. A., Anaele, O., Anthony, T. J. (2011). Studies on prevalence and risk factors for Hepatitis B surface antigen among secondary school students in north central, Nigeria. Sierra Leone Journal of Biomedical Research, 3(3), 163-168. Google Scholar

Obi, P. (2016). High cost of Hepatitis vaccine stalls inclusion in nation wide immunization programme. Retrieved from http://www.thisdaylive.com/index.php/2016/04/25/high-cost-ofhepatitis-vaccine-stalls-inclusion-in-nationwide-immunization-programme/

Google Scholar

Odimayo, M. S., Nwadioha, S. I., Utoo, P. M. (2015). Level of awareness of Hepatitis B viral infection among a subset of Makurdi community in Benue State, Nigeria. British Microbiology Research Journal, 7(1), 28-34.

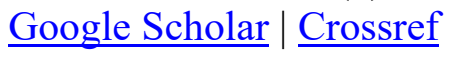

Oduaran, C., Okorie, N. (2018). Community radio, family and psychological support for sexual harassment issues against women: A study of Yoruba usage. Media Watch Journal, 9(3), 291301.

Google Scholar 
Okorie, N., Bigala, P. (2016). Creating HIV/AIDS awareness through localized communication for health development in South Africa. Journal of Health Management, 18(3), 439-446.

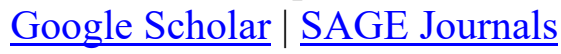

Okorie, N., Bwala, N. (2017). Measuring media campaigns effectiveness for environmental health for sustainable development: A study of Ebola outbreak in Lagos State, Nigeria. Journal of Health Management, 19(4), 1-10.

Google Scholar

Okorie, N., Salawu, A. (2016). Effective use of media awareness campaigns for breast cancer care among woman: A comparative study. Journal of International Women's Studies, 17(4), 160-173.

Google Scholar

Okorie, N., Oyesomi, K., Olushola, O., Olatunji, R. W., Ebenezzar, O. S. (2014). Effective use of information sources for breast cancer care: Interplay of mass media and interpersonal channels. Journal of African Research in Business and Technology. DOI:10.5171/2014.152107

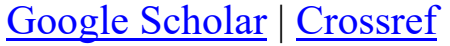

Ola, S. O., Otegbayo, J. A., Yakubu, A., Odaibo, G. N., Olaleye, D. O. (2009). Nigerian butchers and Hepatitis B virus infection. Tropical Gastroenterology Quarterly Reviews. Retrieved from http://dx.doi.org/

Google Scholar

Olalekan, A. W. (2015). Prevalence and risk factors for Hepatitis B and C among sexually active undergraduates in southwestern Nigeria. Annals of Tropical Medicine and Public Health, $8(6), 235-240$.

Google Scholar $\mid \underline{\text { Crossref }}$

Olokoba, A. B., Aderibigbe, S. A., Kayode, O. O. (2010). A community survey of practices related to risk factors for liver disease among adults in Ilorin metropolis. American Journal of Science and Industrial Research, 1(2), 118-121.

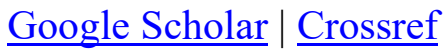

Olotu, O. (2017, March 8). Lagos State Information Centre, Viral Hepatitis Association of Nigeria (VHAN), Plot 2, Bayode Oluwole Close, by Balogun Bus-stop, off Awolowo Road, Ikeja.

Google Scholar

Onehi, V. (2015, July 15). 20m Nigerians infected with Hepatitis virus-FG. Daily Trust.

Retrieved from http:/www.dailytrust.com.ng/daily/index.php/news-menu/news/59986-20mnigerians-infected-with-hepatitis-virusfg?

Google Scholar 
Salem, R. M., Bernstein, J., Sullivan, T. M. (2008). Tools for behaviour change communication (INFO Reports). Baltimore, MD: John Hopkins Bloomberg School of Public Health.

Google Scholar

Sali, S., Bashtar, R., Alavian, S. M. (2005). Risk factors for chronic Hepatitis B infection. Hepatitis Monthly, 5(4), 111.

Google Scholar

Shagamana, Y. N. (2016). An appraisal of communication approaches of Viral Hepatitis Association of Nigeria, on hepatitis intervention in Kaduna State. A dissertation presented to the Post-Graduate School, Ahmadu Bello University, Zaria.

Google Scholar

US Centre for Disease Prevention and Control . (2016). Hepatitis B FAQs for health proffesionals. Retreived from https:/www.cc.gov/hepatitis/hbv/hbvfaq.htm

Google Scholar

World Health Organization (WHO) . (2016). Hepatitis B fact sheet. Retrieved from http://www.who.int/mediacentre/factsheets/fs204/en/

Google Scholar

Article available in:

Vol 21, Issue 2, 2019

SAGE Recommends

\section{Also from SAGE Publishing}

\section{SAGE Journals}

\section{Journal of Health Management}

ISSN: 0972-0634

Online ISSN: 0973-0729

Copyright $(\mathrm{C} 2020$ by Indian Institute of Health Management Research, Jaipur 